\title{
A scientific note on the 'Liebefeld Method' to estimate honey bee colony strength: its history, use, and translation
}

\author{
Benjamin DAINAT ${ }^{1}$, Vincent DietemanN ${ }^{1}$, Anton IMdORF $^{2}$, Jean-Daniel ChARrière $^{1}$ \\ ${ }^{1}$ Swiss Bee Research Centre, Agroscope, CH-3003, Bern, Switzerland \\ ${ }^{2}$ Thurnenweg 2, CH-3127, Mühlethurnen, Switzerland
}

Received 18 July 2019 - Revised 31 October 2019 - Accepted 11 December 2019

Apis mellifera / colony development / colony strength / colony estimation / honey bee health

The strength of honey bee (Apis mellifera) colonies is vital for successful beekeeping. This parameter influences the amount of honey produced (Farrar 1937) and the number of foragers available to perform pollination services (Harbo 1986; Szabo and Lefkovitch 1989; Liebig 1993; Keller et al. 2005) and reflects its health and fitness (Imdorf et al. 2010; Dainat and Neumann 2013). Thus, there is a need for beekeepers and researchers interested in colony performance and vitality to have a reliable tool for measuring colony strength and development over time. Determining the status of a colony (i.e. healthy and productive or weak) requires the counting of thousands of highly mobile adult insects, of larvae lodged at the bottom of wax cells and of cells containing food stocks. A method allowing for such estimations was first described in 1987 in Apidologie in German. Here, we describe the history and principles of this easy, cost-efficient, reproducible and standardized field

Electronic supplementary material The online version of this article (https://doi.org/10.1007/s13592-019-00728-2) contains supplementary material, which is available to authorized users.

Corresponding author: B. Dainat, benjamin.dainat@agroscope.admin.ch Handling Editor: Peter Rosenkranz method that improved previous procedures and which later became known as the 'Liebefeld Method'. This method rapidly delivers reliable data on a large number of colonies, which is an advantage for beekeepers and researchers who require a large amount of high-quality field data. Although it has been widely used, the original language of the publication describing the estimation procedure likely reduced its international impact. Due to the continued relevance of this method today, the original article has been translated into English, and the citable article (DOI https://doi.org/10.5281/zenodo.3341580) is now freely available in a repository with permanent access (https://zenodo. org/record/3341580).

\section{Q U A N T I F Y I N G C L O N Y STRENGTH}

Researchers have long been interested in understanding the population dynamics of honey bee colonies. In 1850, the German entomologist August von Berlepsch quantified the number of eggs a healthy queen could lay and reported a maximum fecundity of 1200 eggs per day (Berlepsch 1873). More than a century later, between the 1960s and the 1980s, Gerig, Imdorf, 
Wille, and co-workers developed a method to easily and rapidly quantify colony strength (i.e. the number of adult workers and amount of brood and food storage cells) by visual estimation in a standardized manner (Imdorf et al. 1987). This method was later named the Liebefeld Method after the town in Switzerland where the authors' honey bee research institute was located. Testifying of the acceptance and common use of the method, German apidologist created the verb 'liebefeldern' to designate the action of estimating colony strength.

\section{USE OF THE LIEBEFELD METHOD OVER TIME}

From the 1960s onward, the Liebefeld Method was routinely used at the Swiss Bee Research Centre (Wille 1967; Wille and Gerig 1976) to study colony development (i.e. demographical changes over time), food storage dynamics, brood production and the lifespan of adult workers, in addition to the influence of the location of apiaries and of farming practices on honey bee health (Charrière et al. 2010; Gallot et al. 2016). Researchers also utilized this method to evaluate the effect of Varroa destructor control measures (e.g. drone removal, colony splitting, formic and oxalic acid treatments) on colony development (e.g. Imdorf et al. 2010). Shortly after its publication, other German-speaking honey bee research institutes adopted the Liebefeld Method in studies of the impact of beekeeping practices and diseasecontrol on colonies (Kovac 1988; Büchler 1992). Later, the method was applied to similar research topics in many countries (e.g. Pietropaoli and Formato 2017; Kovačić et al. 2018; Lodesani et al. 2019; Osterman et al. 2019), as well as in a large-scale pan-European study that compared colony development in different climatic regions and investigated genotype/environment interactions (Büchler et al. 2014). Furthermore, the Liebefeld Method was used as the basis to design the standard method to estimate colony strength in the BEEBOOK (Delaplane et al. 2013). Multiple citations in scientific journals (CrossRef, $n=55$; Web of Science, $n=72$; Google Scholar, $n=105$, accessed 24/05/19) attest of the use and usefulness of the Liebefeld Method. However, the number of

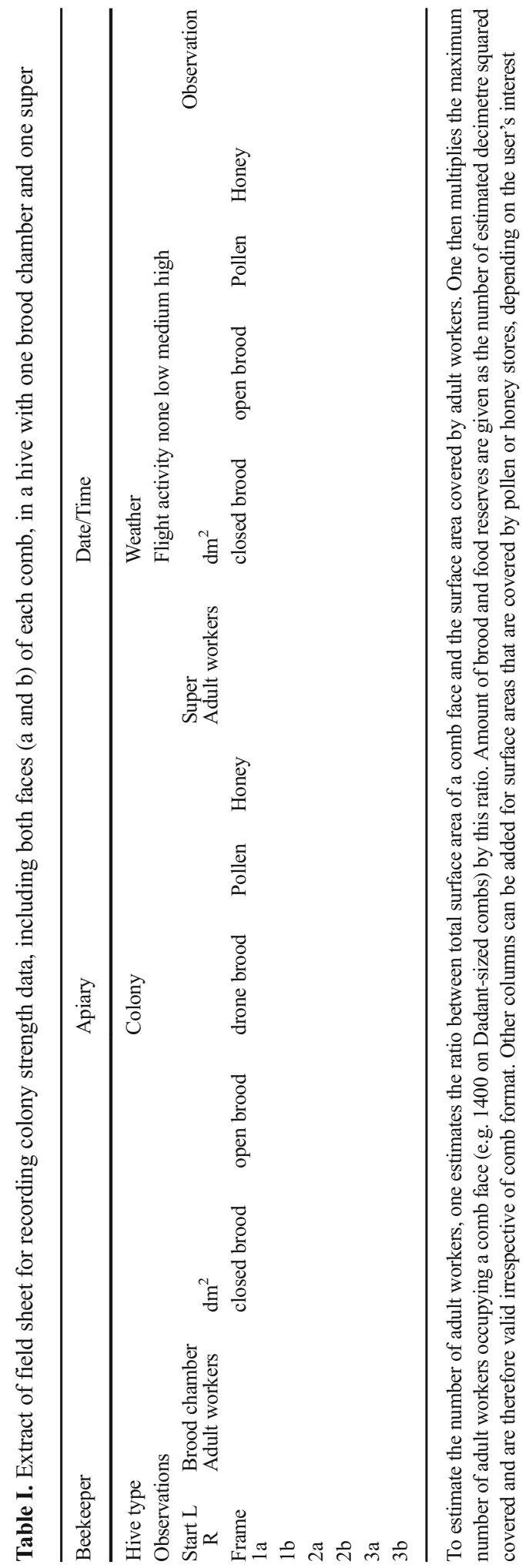


citations is relatively low for a two-decade old article, which is certainly due to its original publication language. To make this method more broadly available, we have provided a freely accessible and citable translation of the original article in English (https://zenodo. org/record/3341580).

\section{PRINCIPLES OF THE LIEBEFELD METHOD}

The Liebefeld Method is based on a visual estimation of the number of adult workers covering each comb side and beneath them, of the surface area $\left(\mathrm{dm}^{2}\right)$ of the comb that is occupied by the open brood, capped brood, honey and pollen stores. The number of adult workers is estimated in absolute values rather than square decimetres to adjust, in real time, for variable worker density on a comb (i.e. workers in overlapping layers or with their bodies in cells). The data can be recorded either on paper or in a digital field sheet (Table I and Supplementary File 1). Table II indicates, for different frame formats, the total surface area of one side of a comb and the maximum number of adult workers that can occupy it. A spread sheet with automatic conversion of comb surface to the number of cells according to their width is available in Supplementary File 1.

\section{TRAINING}

An online module based on 108 images of Dadant Blatt and Swiss-type combs with known numbers of adult workers allows users to practice the Liebefeld Method with a low logistical investment. The module is available on the website of the Swiss Bee Research Centre (www.agroscope.admin.ch/liebefeldtraining). However, regular calibration is required to accurately associate the users' estimates to the absolute number of adult workers on combs. The latter can be achieved by brushing all the honey bees into a box and weighing them after population estimation in the field (Imdorf et al. 1987). The accuracy of experienced users' estimations of adult worker population sizes exceeded 96\% (Imdorf et al. 1987). Calibration for brood estimations can be performed by subdividing an empty frame into square decimetres with strings and superimposing it on the comb under scrutiny (Imdorf et al. 2010). The accuracy of capped brood estimation was high (99\%), whereas the accuracy of open brood estimation was lower (65\%) (Imdorf et al. 1987).

\section{ADVANTAGES AND LIMITATIONS OF THE LIEBEFELD METHOD}

Without the need to remove workers from the combs, the Liebefeld Method is simple and fast. An experienced observer spends approximately 10 min per colony kept in an 11-frame Dadant Blatt hive. The method thus allows the strength of many colonies in the field to be estimated in a single day. Application of the method every 3 weeks, which is the developmental period of an Apis mellifera worker, enables accurate quantification of a colony's

Table II. Reference values for the estimation of adult workers covering combs of different hive types according to Imdorf et al. (2010) (based on wax foundation sheet size)

\begin{tabular}{llll}
\hline Comb type & $\begin{array}{l}\text { Surface }\left(\mathrm{dm}^{2}\right) \text { per face } \\
\text { of a hive body comb }\end{array}$ & $\begin{array}{l}\text { Surface }\left(\mathrm{dm}^{2}\right) \text { per face } \\
\text { of a super comb }\end{array}$ & $\begin{array}{l}\text { Worker counts } \\
\text { per face of a hive body comb }\end{array}$ \\
\hline Swiss type & 8.5 & 4 & 1200 \\
Dadant Blatt & 11 & 5.5 & 1400 \\
German norm & 7 & 7 & 900 \\
Deep Langstroth & 8.5 & 4.5 & 1100 \\
Zander & 7.5 & 7.5 & 1000 \\
\hline
\end{tabular}


demographic dynamics (Bühlmann 1985). Although the method is mildly invasive due to repeated colony opening and frame extraction, it has no measurable negative effects on colony development (Imdorf et al. 1987; Imdorf and Maquelin 1993; Liebig 1994). Contrary to the belief of many beekeepers, colony strength can be estimated in spring or autumn, when temperatures range between 10 and $15{ }^{\circ} \mathrm{C}$, without negatively affecting colonies (Imdorf and Maquelin 1993).

Colony strength estimations performed late in the honey bee season when resources decrease can trigger robbing. This problem can be reduced by physically restricting the opening through which combs are taken out of the colony or by working under a tent. Estimating the colony strength early in the morning or late in the day can also reduce the likelihood of robbing. Liebefeld estimations performed before or after the honeybees leave the hive capture the total number of adults in a colony. However, in large experiments, it is not feasible to evaluate all colonies when the foragers are still in the hives. In such cases, the daily variations of external factors affecting foraging activity, such as excessive heat or bad weather, can be evened out by alternating the colonies estimated between experimental groups (Imdorf et al. 2010).

\section{OTHER METHODS FOR E S T I M A T I N G C O L O N Y STRENGTH}

During the past 25 years, other methods for estimating colony strength have been developed (Burgett and Burikam 1985; Marchetti 1985; Skinner et al. 2001; Gris 2002; Delaplane et al. 2005; Delaplane et al. 2010; Guzman-Novoa et al. 2011; Avni et al. 2014). These are based on the same general principle as that of the Liebefeld Method (i.e. either visually estimating comb surfaces covered by brood and adult workers or analysing images of combs taken in the field and/or laboratory; Cornelissen et al. 2009; Wilson and Johnson 2011; Jeker et al. 2012; Avni et al. 2015; Hoeferlin and Hoeferlin 2015; Colin et al.
2018; Wang 2019). Current image-based techniques for brood area and store size estimation are more invasive than the Liebefeld Method because they require removal of the adult workers from the combs. In addition, colony strength estimation methods that rely on technology can suffer from practical limitations (e.g. beekeeping gloves not compatible with sensitive electronic devices, screens not conducive to reading in the field due to strong sunlight, and long transport distances between colony sites and laboratory facilities). A recent study concluded that the Liebefeld Method produced estimates of colony strength faster than an image analysis program did and that the method was reliable, reproducible and introduced no user bias, making it optimally suited as a field method (Bargen et al. 2019).

A quarter of a century ago, the Liebefeld Method established the fundamentals for efficiently and accurately quantifying colony strength and for monitoring colony development over time. New technologies cannot at present compete with the human eye to measure these parameters. By improving access to the Liebefeld Method, we hope to promote further development and automation of this fundamental tool for beekeepers and honey bee researchers.

\section{ACKNOWLEDGMENTS}

We are grateful to Benoît Droz and Matthieu Guichard for their valuable comments on an earlier version of the manuscript. We also thank Benoit Droz for preparing the downloadable spreadsheets.

\section{CONTRIBUTIONS}

BD wrote the first draft, BD, VD, AI, JDC participated in revisions.All authors read and approved the final manuscript.

\section{FUNDING INFORMATION}

We are grateful to Agroscope for their funding support. 


\section{OPEN ACCESS}

This article is licensed under a Creative Commons Attribution 4.0 International License, which permits use, sharing, adaptation, distribution and reproduction in any medium or format, as long as you give appropriate credit to the original author(s) and the source, provide a link to the Creative Commons licence, and indicate if changes were made. The images or other third party material in this article are included in the article's Creative Commons licence, unless indicated otherwise in a credit line to the material. If material is not included in the article's Creative Commons licence and your intended use is not permitted by statutory regulation or exceeds the permitted use, you will need to obtain permission directly from the copyright holder. To view a copy of this licence, visit http://creativecommons.org/ licenses/by/4.0/.

Note scientifique sur la «Méthode Liebefeld» pour l'estimation de la force des colonies d'abeilles mellifères: historique, application et traduction

Apis mellifera / développement des colonies / force des colonies / estimation des colonies / santé des abeilles.

Eine wissenschaftliche Notiz betreffend der «Liebefelder Methode» zum Schätzen der Volksstärke von Honigbienen: Geschichte, Anwendung und Übersetzung

Apis mellifera / Volksentwicklung / Volksstärke / Volksabschätzung / Honigbienengesundheit.

\section{REFERENCES}

Avni D., Hendriksma H.P., Dag A., Uni Z., Shafir S. (2014) Nutritional aspects of honey bee-collected pollen and constraints on colony development in the eastern Mediterranean, J. Insect Physiol. 69, 65-73.

Avni D., Kielmanowicz M., Inberg A., Golani Y., Lerner I.M, Gafni G., Mahler T. (2015) Quantitative analytical tools for bee health (Apis mellifera) assessment, Julius-Kühn-Archiv 450, 103-110.

Bargen H., Fauser A., Gaetschenberger H., Gonsior G., Knaebe S. (2019) Bee colony assessments with the Liebefeld method: How do individual beekeepers influence results and are photo assessments a possibility to reduce variability? SETAC Europe 29th Annual Meeting, Society of Environmental Toxicology and Chemistry Europe (SETAC Europe), Helsinki.
Berlepsch A. (1873) Die Biene und ihre Zucht mit beweglichen Waben in Gegenden ohne Spätsommertracht. J. Schneider, Mannheim.

Büchler R. (1992) Population dynamics of honeybee colonies with regard to infestation level. Apidologie 23 (4): 377-379.

Büchler R., Costa C., Hatjina F., Andonov S., Meixner M.D., et al. (2014) The influence of genetic origin and its interaction with environmental effects on the survival of Apis mellifera L. colonies in Europe, J. Apicult. Res. 53 (2): 205-214.

Bühlmann G. (1985) Assessing population dynamics in a honeybee colony. Mitteilungen der Deutschen Gesellschaft für allgemeine und angewandte Entomologie 4 : 312-316.

Burgett M., Burikam I. (1985) Number of adult honey bees (Hymenoptera: Apidae) occupying a comb: A standard for estimating colony populations, J. Econ. Entomol. 78(5): 1154-1156.

Charrière J.D., Imdorf A., Koenig C., Gallmann S., Kuhn R. (2010) Do sunflowers influence the development of honey bee, Apis mellifera, colonies in areas with diversified crop farming?, J. Apicult. Res. 49 (3): 227235.

Colin T., Bruce J., Meikle W.G., Barron A.B. (2018) The development of honey bee colonies assessed using a new semi-automated brood counting method: CombCount, PLOS ONE 13(10): e0205816.

Cornelissen B., Blacquière T., Van der Steen J. (2009) Estimating honey bee colony size using digital photography, 41st International Apicultural Congress Apimondia, Montpellier.

Dainat B., Neumann P. (2013) Clinical signs of deformed wing virus infection are predictive markers for honey bee colony losses, J. Invertebr. Pathol. 112 (3): 278280.

Delaplane K.S., Berry J.A., Skinner J.A., Parkman J.P., Hood W.M. (2005) Integrated pest management against Varroa destructor reduces colony mite levels and delays treatment threshold, J. Apicult. Res. 44 (4): $157-162$.

Delaplane K.S., Ellis J.D., Hood V.M. (2010) A test for interactions between Varroa destructor (Acari: Varroidae) and Aethina tumida (Coleoptera: Nitidulidae) in colonies of honey bees (Hymenoptera: Apidae), Ann. Entomol. Soc. Am. 103 (5): 711-715.

Delaplane K.S., van der Steen J., Guzman-Novoa E. (2013) Standard methods for estimating strength parameters of Apis mellifera colonies, J. Apicult. Res. 52 (1).

Farrar C.L. (1937) The influence of colony populations on honey production, J. Agric. Res. 54 (12): 945-954.

Gallot M., Buchwalder G., Beuret B., Cecilio J.M., Guinemer M., et al. (2016) Autumn intermediate crops and development of honey-bee colonies, Agrarforsch Schweiz 7 (3): 120-127.

Gris A. (2002) Efecto de las diferencias en población entre colonias de abejas (Apis mellifera L.) con una y dos 
reinas en el comportamiento productivo y de pecoreo de sus obreras, National University of Mexico, Mexico , pp. 47.

Guzman-Novoa E., Benitez A.C., Montano L.G.E., Novoa G.G. (2011) Colonization, impact and control of Africanized honey bees in Mexico, Vet. Mexico 42 (2): 149-178.

Harbo J.R. (1986) Effect of population size on brood production, worker survival and honey gain in colonies of honeybees, J. Apicult. Res 25(1): 22-29.

Hoeferlin B., Hoeferlin M. (2015) HiveAnalyzer.

Imdorf A., Bühlmann G., Gerig L., Kilchenmann V., Wille H. (1987) Überprüfung der Schätzmethode zur Ermittlung der Brutfläche und der Anzahl Arbeiterinnen in freifliegenden Bienenvölkern. Apidologie 18(2): 137-146.

Imdorf A., Maquelin C. (1993) Estimation printanière des colonies d'abeilles. Journal Suisse d'apiculture 90 (1112): 433-437.

Imdorf A., Ruoff K., Fluri P., Gallmann P. (2010) Le developpement des colonies chez l'abeille mellifère, ALP Forum $68: 1-67$.

Jeker L., Schmid L., Meschberger T., Candolfi M., Pudenz S., et al. (2012) Computer-assisted digital image analysis and evaluation of brood development in honey bee combs, J. Apicult. Res. 51 (1): 63-73.

Keller I., Fluri P., Imdorf A. (2005) Pollen nutrition and colony development in honey bees - Part II, Bee World 86 (2): 27-34.

Kovac H. (1988) Die Befallsentwicklung der Milbe Varroa jacobsoni Oudemans in Bienenvölkern und Auswirkungen der Parasitierung auf die Einzelbiene Apis mellifera carnica Pollm., Universität Graz.

Kovačić M., Puškadija Z., Dražić M.M. (2018) Grooming behavior in relation to varroa (Varroa destructor) infestation level of Carniolan honey bee colonies (Apis mellifera carnica), J. Centr. Europ. Agricult 19(4), 959-964.

Liebig G. (1993) Volksstärke und Honigleistung. Deutsches Bienen Journal 1: 14-15.

Liebig G. (1994) Entwicklung von Bienenvölkern - Ergebnisse des Forschungsprogrammes "Volksentwicklung", Festschrift Hohenheim aktuell.
Lodesani M., Franceschetti S., Dall'Ollio R. (2019) Evaluation of early spring bio-technical management techniques to control varroosis in Apis mellifera, Apidologie 50, 131-140.

Marchetti S. (1985) Il "metodo dei sesti" per la valutazione numerica degli adulti in famiglie di Apis mellifera L. Apicoltura 1: 41-61.

Osterman J., Wintermantel D., Locke B., Jonsson O., Semberg E., et al. (2019) Clothianidin seed-treatment has no detectable negative impact on honeybee colonies and their pathogens, Nat. Commun. 10 (1).

Pietropaoli M., Formato G. (2017) Liquid formic acid 60\% to control varroa mites (Varroa destructor) in honey bee colonies (Apis mellifera): protocol evaluation, J. Apicult. Res 57 (2):300-307.

Skinner J.A., Parkman J.P., Studer M.D. (2001) Evaluation of honey bee miticides, including temporal and thermal effects on formic acid gel vapours, in the central south-eastern USA, J. Apicult. Res 40 (3-4): 81-89.

Szabo T.I., Lefkovitch L.P. (1989) Effect of brood production and population size on honey production of honeybee colonies in Alberta, Canada, Apidologie 20 (2): $157-163$.

Wang M. (2019) HoneybeeComplete (colony assessments \& brood trials).

Wille H. (1967) Einfluss der Umgebungstemperatur auf die Entwicklung der Völker im Frühjahr, Schweiz. Bienenztg $90(10,11,12)$ :455-457.

Wille H., Gerig L. (1976) Massenwechsel des Bienenvolkes. IV. Zusammenspiel der Eilegetätigkeit der Königin, der Bienenschlüpfrate und der Lebensdauer der Arbeiterinnen (Apis mellifica L.), Schweiz. Bienenztg $99(1,3,5)$ : 16-25.

Wilson M.E., Johnson R.M. (2011) Broodmapper: Honey Bee Development and Citizen Science. https://articles. extension.org/pages/61320/broodmapper:-honey-beedevelopment-and-citizen-science. Accessed 25 Oct 2019.

Publisher's note Springer Nature remains neutral with regard to jurisdictional claims in published maps and institutional affiliations. 